\title{
The Democratic Duty to Educate Oneself
}

\author{
Steinar Bøyum
}

Department of Education, Faculty of Psychology, University of Bergen, steinar.boyum@uib.no

DOI: http://dx.doi.org/10.5324/eip.v12i2.2515

(cc) BY This is an open access article distributed under the terms of the Creative Commons Attribution 4.0 International License, which permits unrestricted use, distribution, and reproduction in any medium, provided the original author and source are credited.

I argue that democratic citizens have a duty to educate themselves politically. My argument proceeds in two stages. First, I establish a case for the moral importance of individual competence for voting, but I also maintain that the substantial content of the required competence must remain open. I do this by way of assessing Jason Brennan's provocative defense of epistocracy. I try to show that there is no notion of political competence that can meet with reasonable agreement among citizens and that voter qualification exams are therefore illegitimate. Second, I maintain that the basic premise of Brennan's argument, the right to a competent electorate, is valid and that it corresponds to an individual duty to educate oneself politically. This duty is, in Kant's terminology, a wide and imperfect duty that we owe to our fellow democratic citizens. Yet since the content of competence must be left open, this moral duty cannot be transformed into a legal obligation.

Keywords: competence, democracy, duty, education.

\section{Introduction}

Most of us would agree that democracy depends on education. In the words of John Rawls, "without widespread education in the basic aspects of constitutional democratic government for all citizens, and without a public informed about pressing problems, crucial political and social decisions simply cannot be made" (1997: 773). Or more precisely, decisions can certainly be made with an ill-informed public, but they are more likely to be bad ones, with potentially disastrous consequences. With that in mind, the great interest in democratic education recently is unsurprising. The focus of that interest has usually been on either the prudence or the obligation of the state, schools or parents to provide the education necessary for democratic participation. However, I would argue that it is also the responsibility of the individual citizen to acquire that education. We owe it to our fellow citizens to educate ourselves politically.

The present article consists of two parts. In the first part, I establish a prima facie case for the moral importance of individual competence for democratic participation, but also that the substantial content of the required competence is open-ended. I do this by way of assessing Jason Brennan's provocative argument against universal suffrage (Brennan 2011). Brennan adopts a principle of 
competence asserting that citizens have a right to a competent electorate, which in turn leads him to support a version of epistocracy. ${ }^{1}$ I shall argue that his argument is not valid, due to the disputed nature of the required competence. Reasonable disagreement about competence leads to reasonable disagreement about any voter exam. This does not mean that the notion of competence is morally irrelevant, but it means that the content of the required competence is best thought of as openended. In the second part, I argue that the basic premise of Brennan's argument, the right to a competent electorate, holds true in the sense that we have a moral right to expect others to base their participation in democratic decision-making on relevant knowledge. Moreover, this legitimate expectation gives rise to an individual duty on behalf of citizens: the democratic duty to educate oneself politically. ${ }^{2}$ I then outline the main features of the duty to educate oneself: what kind of duty it is; who owes it and to whom; what is owed and how much; and what follows if the duty is not discharged. By exploiting some of Kant's moral vocabulary, I argue that the political duty to educate oneself is a wide and imperfect duty that we owe to our fellow democratic citizens. ${ }^{3}$

I shall make two assumptions. First, I shall assume that citizens do have some influence on policy through political participation, such as voting. Otherwise, it would hardly be a democracy. That does not mean that citizens have all the power: modern democracies are characterized by a complex epistemic division of labor, where experts, bureaucracies, and political parties, to name a few, also play important roles. Hence, citizens' input is only a part, albeit an important part, of the collective decision-making process. I argue that even that limited part is significant enough to be accompanied by civic obligations. Second, I shall assume that basing decisions on better knowledge will usually lead to better decisions in the long run, so that widespread voter ignorance is at least a problem (Somin 2015). I shall leave the precise meaning of "better knowledge" open for now, for reasons that will soon become clear, and I shall also leave open what "better decisions" means: it can be read as "decisions contributing to a good and just society", where the precise meaning of "good and just" is left open for the reader to fill in, according to his or her convictions.

\section{The Problem of Competence}

I shall start by outlining Jason Brennan's argument against universal suffrage. The first premise of that argument is that to vote is to exercise significant power over others. This claim has three aspects. First, to vote is to exercise power. Collectively, voters create or uphold laws that are imposed on citizens by force. Even democratic governments threaten violence in order to induce compliance with their laws. Second, to vote is to exercise significant power. The significance of our individual vote may be negligible, but collectively, voting can do great harm. ${ }^{4}$ Elected governments can alter citizens' life prospects in dramatic and even disastrous ways, for instance, through waging wars or making economic policy. Third, to vote is to exercise significant power over others. In voting, we make decisions not only for ourselves, but for others. And whereas we may have a basic right to have a say in matters concerning ourselves, a corresponding basic right to govern others does not seem to exist. This power needs to be justified. 
The second basic premise of Brennan's argument is what he calls the principle of competence: "Citizens have a right that any political power held over them should be exercised by competent people in a competent way" (2011: 700). Brennan's justification for this principle proceeds mainly by analogy to the case of juries, to which we shall return. It follows from these two premises that we have a right to a competent electorate, and that incompetent voting is unjust. Hence, we owe it to each other to exercise the right to vote in a competent manner. That is the core of Brennan's argument.

Obviously, a lot hangs on the meaning of "competence". Although Brennan does not give us a detailed account, we can deduce from his text three dimensions of competence. First, being competent includes having the requisite relevant knowledge, the opposite of which is ignorance. Second, being competent includes a certain quality of reasoning: how you assess evidence, draw inferences, and so on. The opposite is irrationality. Third, competence includes a moral component: voters should be reasonable. That is not to say that we must have the correct moral beliefs, but it invokes a common idea within political or public reason liberalism, such as the core idea of Rawls' version of political liberalism. However, Brennan wants to leave the content of "reasonable" open, "to be filled in by the truth, whatever that is", apart from noting that reasonableness excludes patent moral failings like racism (Brennan 2011: 705). His argument is therefore assumed to hold independently of any specific conception of moral reasonableness.

The controversial parts of Brennan's argument come from what he thinks the principle of competence implies. His argument would be philosophically significant, but practically inconsequential if all voters were competent. Yet Brennan brings his philosophical argument to bear on an empirical claim: Many citizens are incompetent, in the sense of ignorant, irrational, and/or unreasonable (2007). Even this claim would not be overly radical if the right to vote took precedence over the right to a competent electorate. Yet Brennan holds that if citizens are not competent, they ought to be excluded from holding political power, including the power to vote. Only citizens of sufficient political competence should be allowed to vote. Epistocracy is more just than democracy.

Brennan's conclusions are provocative and hard to swallow. He provides us with two sets of considerations to make them more palatable.

The first is the jury analogy. Like voters, jurors wield significant power. Their decisions can have serious consequences for the defendant's life prospects. In a jury context, however, we already accept something like the principle of competence. Imagine that the jury is ignorant (jurors pay no attention during the trial and are ignorant of what the case is about), irrational (jurors make their decision "not on the basis of the evidence, but on the basis of wishful thinking and various bizarre conspiracy theories") or unreasonable (the jury finds the defendant guilty because he is black, gay, or Muslim) (Brennan 2011: 703). To knowingly enforce decisions made from these kinds of serious epistemic or moral failings would be unjust. Hence, we rightly take steps to avoid such incompetencies in a jury context.

In the political context, however, many voters do the equivalent of the above juror incompetencies without anyone calling for them to be disenfranchised (except Brennan). We acknowledge the right of defendants to competent juries, but not the right of citizens to competent voters, even though the decisions voters make are just 
as serious, perhaps even more so. Brennan asks us to consider the political parallels to the juries above: The ignorant electorate, where voters pay no attention to the details of the election, have little or less knowledge of the issues at stake, and in effect choose their candidate at random; the irrational electorate, where voters pay some attention and have some knowledge of the issues, but vote "on the basis of wishful thinking and various disreputable social scientific theories they happen to believe"; and the unreasonable electorate, where voters choose the white candidate rather than the black out of sheer racism (Brennan 2011: 708). Voters like this exist, and may even admit it openly, but still, Brennan notes, nobody seems to bother about the injustice of having such voters participate in decision-making with potentially serious effects for other citizens.

The second strategy that Brennan employs to break down our resistance to his epistocratic conclusion is the argument from children. Epistocracy seems outrageous to us because we associate it with earlier practices of restricted suffrage, in particular the racist literacy tests in some American states in the first half of the twentieth century. Brennan argues that although people used to be excluded from voting for morally irrelevant reasons (sex or color), that does not make it wrong to exclude them for morally relevant reasons (competence). The moral relevance of competence is salient from the fact that we already deny a significant part of the population the right to vote because they are deemed incompetent: namely, children. Many adults are however less competent than many children, and instead of setting the limit arbitrarily at a certain age, we should rather restrict the right to vote to those who are deemed competent, Brennan argues. Competence, regardless of age, is the morally relevant limiting factor.

We can argue against Brennan's position in several ways. Some of them will take us deeply into general political philosophy. ${ }^{5}$ Since my interest is primarily in the political philosophy of education, I shall here consider only one type of criticism, revolving around the concept of competence. Hopefully, this criticism will be sufficient to at least force a modification of Brennan's claim.

Brennan himself discusses a criticism arising from what he, following Estlund, calls the qualified acceptability requirement. This principle requires that "any basis for the distribution of political power must be justifiable to all qualified points of view" (Brennan 2011: 701). ${ }^{6}$ Brennan notes that one way to implement his version of epistocracy would be by way of a voter qualification exam, which would test citizens for relevant competence: "The purpose of the exam would be to exclude badly incompetent citizens from voting, by screening out citizens who are badly misinformed or ignorant about the election" (2011: 714). Yet Estlund had earlier argued that such an exam would violate the qualified acceptability requirement: We cannot expect all, even all reasonable people, to agree on such a test (Estlund 2008: 33).

Brennan grants that epistocracy violates the qualified acceptability requirement-to a degree. He argues, however, that democracy and epistocracy are in the same boat in that they each violate one basic principle, the competence principle and the qualified acceptability requirement, respectively. Yet violating the competence principle is the more unjust of the two, he claims. We cannot go into the details of that comparison here. ${ }^{7}$ It is more important for our purposes that in his comparison of the relative injustice of the various violations, he seems to ignore 
the deeper aspect of how epistocracy violates the qualified acceptability requirement. It is not just the voting test that will have trouble meeting that requirement, but the underlying account of competence itself. Earlier on Brennan states, "We cannot expect all reasonable people to agree on where the line should be drawn between competence and incompetence" (2011: 714). Yet later he writes as though the problem was merely one of agreeing about a test. In doing so, Brennan may underestimate the depth of the voter exam's violation of the qualified acceptability requirement. The problem is not merely one of constructing an acceptable test, but that there will be a partly political disagreement about what competence to require.

The problem may at first be approached as a threshold problem. How much does someone need to know in order to count as competent? How do we decide where to draw the line between pass and fail, competent and incompetent? In school settings, there are two ways of doing that. The first is to decide on a particular distribution in advance, say, a normal distribution. Under these conditions, someone who passed this year may be less competent than someone who failed last year. The other method is to develop criteria for passing: any graduate should know this and that. It is then an open question how many will pass the exam in a given year: none may pass, or everyone may pass. This second method must be the one that Brennan has in mind. Yet what are the criteria for using certain benchmarks instead of others? Within a school setting there are ways of answering that question. In some cases, the threshold is set by external standards, for instance what is necessary to do a proper job. In medicine, a future nurse must be able to take a blood test without killing the patient. In other cases, standards within a scholarly community provide the threshold. All philosophers think all philosophers should know certain things about Plato and Kant. In most cases a mix of internal and external standards probably applies. Yet regarding voter competence, no external standards and no expert community exist. There is no external standard because we have different ideas of what a proper society is, and there is no expert community apart from the people themselves.

This lack of standards and experts leads us to the deeper problem: there is reasonable disagreement about what should be known in order to take part in governing others through voting. Brennan may say that without an elementary understanding of economics you would lack something crucial for governing. Others might reply that without having immersed yourself in literature you would lack a capacity for empathy that is even more important for governing. And so on. Admittedly, the economist and the man of letters might agree on a disjunctive account: a voter will have to know either economics or literature. That helps a little, but not much. Some might repudiate the disjunctive account and argue that their favored candidate item for inclusion in the voter exam should be compulsory. Certain areas of knowledge might also be considered positively harmful. A Marxist might find a classical economist to be incompetent, not primarily due to a lack of knowledge, but precisely because of his so-called knowledge. The question here is not whether the Marxist is right in this, but whether his position is within the bounds of reasonable disagreement, which I think it is.

There is also reasonable disagreement regarding the second dimension of competence mentioned above. The debate about whether citizens can legitimately 
rely on religious reasons in politics can, for instance, be seen as a debate about the content of political competence. Does using the Bible as a source of reasons and evidence count as irrationality and thereby as incompetence? If we assume that political philosophers are reasonable, the debate within political philosophy about religion and public reason indicates that we are here dealing with reasonable disagreement about the criteria for competence and incompetence.

One might further argue that the most relevant knowledge, for example about poverty or racism, is not factual or theoretical but experiential or practical. To misuse Russell's famous distinction, is knowledge by description or knowledge by acquaintance more important in a political context? Those who know in one sense (they have read about it) may not know in another sense (they have not felt it on their bodies), and vice versa. It is hard to discern an obvious answer to how much of the first (or second) type of knowledge is needed to compensate for a lack of the other type. Once again, the claim is not that knowledge by acquaintance is necessary, but that it can be reasonably argued that it is, and that a voter test therefore violates the qualified acceptability requirement. Likewise, the point is not just that testing for practical or experiential knowledge is difficult, but that disagreement exists regarding the competence that the exam should test. Even if inventive psychologists manage to devise an exam that tested reliably for this second type of knowledge, the underlying problem of how important it is to the required competence would remain.

This disagreement is also reflected among political philosophers, for instance in controversies over democratic citizenship and civic education. Elizabeth Anderson argues that those who are most competent or qualified to lead in a democratic society must be "systematically responsive to the interests and concerns of people from all walks of life" (2007: 596). To be responsive in this way requires avoiding cognitive biases and group stereotyping. This can only be effectively avoided by personal experience-academic or propositional knowledge is not sufficient. Therefore, the democratic leadership must draw its members from a variety of social and cultural backgrounds. Importantly, Anderson holds diversity of background to be part of the competence of the most competent. Bluntly put, having a disadvantaged background can be an epistemic advantage in a democracy.

I suspect that the problems are even graver when we turn to the moral component of competence. However, Brennan's strategy of leaving open the meaning of both "reasonable" and "qualified" makes it hard to start a productive discussion about whether any conception of moral reasonableness can meet the qualified acceptability requirement. Besides, even assuming such a conception, it is hard to see how one could construct a test for moral reasonableness that would not be fairly easy to fake the correct answers on. Of course, more sophisticated psychological tests can detect racism and implicit bias, for instance, but the more sophisticated the tests, the higher the probability that there is qualified disagreement about them.

To sum up, the problem is not just a matter of devising an exam that tracks "the real difference between competence and incompetence," but that there is reasonable disagreement about what that real difference consists in. It is not just the test itself that gets into trouble with the qualified acceptability requirement, but also what it is to be a test of. So the problem with voter exams is not just one of tracking a 
distinction that all reasonable people accept in a way that not all reasonable people can accept, but that there may not really be a distinction that all reasonable people can accept. ${ }^{8}$

\section{The Duty to Educate Oneself}

In an earlier paper on the same topic, Brennan stated that it was "a piece of moral philosophy, not a manual for civic education" (2009: 547). The concerns raised above should make us doubt whether a detailed manual could ever meet the qualified acceptability requirement and thus be made compulsory for voting. Still, Brennan's argument is a reminder that civic education is necessary for responsible voting, and that we may have understated the duties that accompany democratic participation, including voting. By arguing forcefully that individuals have a right to a competent electorate, he also points us towards a corresponding individual duty, and thus that acquiring civic education is partly the responsibility of the citizen herself.

A great deal of concern about democratic education has been raised in the last couple of decades. Insofar as it has been thought of as a duty, however, it is ordinarily understood as the duty of others (state, schools, or parents) to provide that education, and the right of the individual (child or citizen) to receive it. My claim now is that democratic citizens also have a duty to educate themselves, in both the epistemic and ethical senses mentioned above. Let us call this the democratic duty to educate oneself politically. I suggest, though, that given the wide, deep and reasonable disagreement noted above about what and how much knowledge to require, it is best to think of the content of this duty as open: there are many different ways to fulfill it. The duty must therefore be formulated as a duty to acquire the type and amount of knowledge one genuinely and reasonably thinks is necessary to fulfill the principle of competence.

The first question that arises here is whether this is a duty to educate oneself or a duty to try to educate oneself. This trades on an ambivalence in the concept of education. If we restrict the concept of education to processes where we acquire truths and not only beliefs, we must formulate the democratic duty as the duty to make an effort to educate oneself, since individuals may work hard to educate themselves about current affairs, but still end up believing many falsehoods, through no fault of their own. In that case, the citizen has still shown his or her fellow citizens the requisite respect. It is, rather, irresponsible ignorance that shows disrespect for one's fellow citizens (2006, pp. 456-458). For the sake of simplicity, though, I shall continue to talk about the duty to educate oneself, although if we have the narrower concept of education in the back of our minds, it should be read as the duty to make a serious effort at educating oneself, within the limits of one's natural talents and practical constraints. ${ }^{9}$

To my knowledge, the explicit claim that we have a duty to educate ourselves is quite rare. When we do meet claims of this kind, they are usually only mentioned in passing. A case in point is Kenneth Lawson. He states that "[we] are morally obliged to be lifelong learners", and that this duty is both "a consequence of citizenship" and "a condition of citizenship" (2007: 109). This seems superficially similar to the point I am trying to make. Unfortunately, Lawson does not follow up and expand on it, so whether it is also substantially similar is difficult to tell. Kenneth Wain (1991) is 
another example. He argues that it is a "duty of membership in the human community" to educate oneself (Wain 1991: 276). Like Lawson, however, Wain does not elaborate on what this duty consists in and on what grounds it rests. The little he says indicates an economic rather than a political justification: in a fast-changing and increasingly technological society, a constant willingness to learn and develop is necessary for productive membership in the community.

The one philosophical context where we regularly find claims about the duty to educate oneself is in connection with Kant's notion of duties to oneself. The duty to educate oneself follows naturally from Kant's assertion that we owe it to ourselves to cultivate our natural powers, both physical and rational, as well as our moral powers (Wood, 2009). This Kantian duty of self-perfection has been employed to argue that we have a duty to ourselves to educate ourselves (Wain 1991). Yet my claim is different in an important respect. The duty to educate oneself politically is a duty towards others, arising out of an ideal of democratic citizenship. I shall now try to shed light on this duty by locating it within Kant's taxonomy of duties in The Metaphysics of Morals (1991), although I do not mean to assume the truth of Kantian moral philosophy as a whole.

The overarching division in Kant's taxonomy of duties is between juridical duties and ethical duties. Juridical duties can be coercively enforced, in particular through legal regulations, whereas ethical duties cannot. While the public can constrain the individual to comply with juridical duties, the individual must constrain himself to comply with ethical duties. The gist of the previous section was that the right to a competent electorate cannot be translated into a corresponding juridical duty, to be enforced, for instance, by mandatory voter exams. The duty to educate oneself politically must therefore be understood as an ethical duty, which does not imply the right of the state to compel adherence. For such compulsion to be legitimate, it would have to satisfy the qualified acceptability requirement, which, we have seen, it does not do.

Ethical duties to others are further divided into duties of respect and duties of love. The essence of duties of respect is that they are owed. Others do not have to show gratitude for your kindness when you comply with a duty of respect. You cannot claim merit for fulfilling it, but are to be blamed if you do not. Duties of love, on the other hand, are not something you owe anyone. Fulfilling such duties is merely meritorious, and failing to do so is not blameworthy. This distinction is often taken to correspond to the distinction between strict (perfect) and wide (imperfect) duties (Wood, 2009). Strict duties admit no exception; there are quite specific actions that they require or forbid. They correspond to maxims that are not even conceivable as universalized. Wide duties, on the other hand, are much more flexible in what they demand of us. They do not require specific actions but rather the pursuit of certain ends that leave the when, how and to what degree up to us. These duties correspond to maxims that are conceivable as universalized, but that we cannot rationally implement as universal laws. These two divisions, between strict and wide duties and between duties of respect and duties of love, are often taken to overlap, on the following ground: Since wide duties do not require particular actions, but rather that we adopt a certain end, performing particular actions to further the obligatory end is merely meritorious, and omitting any of them is not blameworthy. 
However, the democratic duty to educate oneself cuts across these two divisions. On the one hand, educating oneself is a duty of respect. We owe it to our fellow democratic citizens to exercise political power competently. If we do not even make an effort at educating ourselves politically, we show them contempt. Showing respect is not merely a good thing to do, but something we owe others. On the other hand, it is also a wide duty. As argued above, the democratic duty to educate oneself politically does not have a specific content. It gives us wide latitude to decide for ourselves how to discharge it. It directs us to adopt a policy, as it were, but does not specify how or when or to what degree we must implement it, whether, for instance, we should do so by immersing ourselves in economic theory, travelling the world, or reading newspapers. One cannot therefore be blamed for omitting any particular actions to further the obligatory end. It is not merely meritorious, however, to adopt the end. Refusing to care about the end at all is blameworthy.

But if the content of the obligation is unspecified, it seems as though we can never know whether or not someone is pursuing that end. Can a man argue, for example, that he is educating himself politically by drinking beer and watching Baywatch? Hardly, since "unspecified" does not mean that we have no means of passing judgement. Compare with the duty of beneficence: there is great latitude here in what the duty demands. Sometimes you discharge that duty by helping others out, and at other times by not helping them and letting them manage on their own. That does not exclude particular situations arising where we can say definitely that someone failed to comply with the duty. Likewise, not everything will count as discharging the democratic duty to educate oneself, since not everything will count as the required political education. One has to be able to tell a coherent and convincing story about how a pattern of activities can be seen as fulfilling the duty to educate oneself politically. Although a sophisticated viewer may see reality game shows as political allegories and thereby claim to educate himself by watching them, that explanation will not normally do. Perhaps no general rules can be formulated in advance, but in particular situations we can still determine whether the obligatory end has been set as an end. That a duty is wide does not mean that anything goes.

Yet despite the argument from the first half of the paper, to the effect that no specific rules can be given as valid for all, we can list some activities that may typically promote the relevant political education. In my fairly traditional opinion one should: follow political debate in serious news media; read some important political documents, such as white papers; and study some social science, be it economy, sociology or political science, even if only through popular books. Yet I can also easily imagine a good case being made for other areas of study, like history or law. Even the natural sciences may be politically relevant, such as climate science. A case can also be made for art. Martha Nussbaum has famously argued that fiction can develop your capacity for empathy in a way that is politically important, even necessary. Others again will emphasize the importance of practical experience: work, travel, or talking to people from all walks of life. Even thinking can constitute a political education, either through reflection on the political significance of personal experience, or by thinking things through in the manner of political philosophy. The possibilities are almost endless. Not everything will count, of course. You need a reasonable justification, which is not to say an unassailable proof, for why the activity in question promotes the knowledge or understanding necessary for political participation. 
A wide duty may seem lax, because of the variety of ways in which it can be discharged. Yet that very same laxity makes wide duties especially taxing, since no fixed point exists at which you can say that you have done your duty-it threatens to become an endless task. How much is required to fulfill a wide duty? It does not seem reasonable to demand "as much as possible". Biological needs, such as sleep and other duties, such as taking care of one's children must be considered. Perhaps one also has a legitimate right, if not a duty, to look after one's own happiness. The duty to educate yourself politically does not command you to sit up at night or neglect your children in order to read white papers. Yet what reasons are acceptable for declining to perform actions that promote the democratic duty to educate oneself? We can here distinguish between a rigorous and a lenient view. ${ }^{10}$

A rigorous view would be that one should do as much as possible to promote a wide duty, provided it does not come into conflict with other duties. If the wide duty comes into conflict with a strict duty, the latter will take priority. If it comes into conflict with other wide duties, we must strike a balance between them as well as we can, in accordance with their weight and significance. Yet even if this view does not demand that we spend all our time on political education, it is still quite rigorous in that it demands that we spends all our time on fulfilling duties. Admittedly, there may be overlap between activities promoting wide duties and activities promoting one's own happiness (Baron \& Fahmy, 2009: 222). Some people enjoy politics, after all. Nevertheless, it may still seem overly moralistic, in the sense that we are asked to justify everything we do in moral terms.

A lenient view would be that concern for one's own happiness is allowed to take precedence over any particular wide duty. Obviously, even this view would require us to comply with strict duties, but it would permit sacrificing the promotion of wide duties when it conflicts with the pursuit of happiness. On this view, then, the democratic duty to educate oneself politically can be set aside not only when it collides with other duties, but also when it collides with the concern for one's happiness. Even if the lenient view does not allow you to completely reject the obligatory aim, but merely to postpone it, we may still suspect that it threatens to evaporate the wide duties, including the duty to educate oneself politically.

It is reasonable to conclude that the rigorous view is too rigorous and the lenient view too lenient. A moderately rigorous view seems to me the most plausible. This view will, like the rigorous view, hold that the various claims on us have to be balanced, but like the lenient view it will also leave room for the pursuit of happiness. It combines these by holding that the concern for happiness is one of those concerns that have to be balanced, as though it were a duty. ${ }^{11}$ Moreover, this moderate view obliges us to seek out a reasonable balance, and that cannot mean to give all weight to one or two concerns. Each duty should be given some weight, though leaving latitude for us to balance them in accordance with our personality, our situation and the moral weight of the duties. Letting a tiny increase in momentary happiness outweigh any wide duty is not striking a reasonable balance, nor is it a reasonable balance to stop taking care of your children in favor of reading political philosophy all night. Still, it would be inappropriate to insist on precise rules here.

One obvious argument against this notion of the democratic duty to educate oneself says that if citizens are not competent, it is not their fault. Rather, it is the 
state and/or the parents that have failed in some way. Education generally, or at least the necessary democratic education, should be the responsibility of the state and/or the parents. Yet two wrongs do not make a right. One might agree that in an ideal world the state and/or the parents would take care of the required democratic education. If they do not, however, we still have to deal with the violations of the right to a competent electorate that occur in the non-ideal world. The correct response to that problem is to hold the individual at least partly responsible for his or her own political education, although we might disagree about how great that part is. Yet acknowledging such a part is sufficient for the argument developed here.

Clearly, children do not bear that responsibility themselves. In their case, the duty falls on the state and/or the parents to provide the necessary education. Yet since we are now dealing with a moral duty and not a legal requirement, we do not have do decide upon a particular age when that duty arises. It seems reasonable to assume that it is a gradual process. You are hardly responsible for your education at all when you are seven years old, more responsible at fifteen, and largely responsible for it at twenty-three. As you grow up, you gradually take over more and more of the responsibility for your own education, and in a complex and rapidly changing world that education is never finished. This is not to deny that others, e.g. represented by the state, have a duty to provide the right conditions even for adults to acquire or continue their education, for instance through support for libraries or serious news media.

The democratic duty to educate oneself politically is a duty you owe to others, by virtue of taking part in collective government, if only through voting. Yet if a citizen does not fulfill that duty, should she then abstain from voting? In an earlier paper, Brennan (2009) argued that incompetent citizens should voluntarily refrain from voting, but not that they should be denied the right to vote. Although the present paper implies that Brennan should have kept to this earlier view, such cases can be difficult. Consider the following: Your wife is very well informed. You normally agree with her. She tells you how to vote. Yet you yourself have not made any effort to learn about the candidates and their policies. In this case, you have not fulfilled your duty to educate yourself, but should you abstain from voting? Analysis and argument can sometimes settle hard cases like these, but grey areas may remain. However, for the purposes of this paper it is sufficient that there can be some clear cases where the duty is not fulfilled. People should be free to watch game shows instead of serious news, but if they almost always watch the former and rarely the latter and take no other steps to inform themselves, they should ask themselves in earnest whether they have made the necessary effort, and whether acting on their right to vote shows their fellow citizens sufficient respect.

\section{Notes}

1 "Epistocracy" refers to a political society where knowledge and competence are legal conditions for holding political power.

${ }^{2}$ The notion of education used in this paper does not refer exclusively or even primarily to formal education.

${ }^{3}$ To a somewhat more limited extent, I think it also applies to non-democratic societies. 
${ }^{4}$ We cannot go into the extensive literature on whether it is irrational to vote (since each single vote does not, on its own, make any difference), as it quickly gets too technical. The important point for our purposes is that even if our personal influence is zero, there are moral principles governing our participation in collective activities (Brennan 2012: 2). Caesar's 60 murderers were all responsible for his death, even if he would equally well have been killed by 59 . It should also be noted that the fact that the effect of the individual vote is negligible is primarily a dilemma for the consequentialist: how can something be right or wrong, obligatory or impermissible, if it is of no consequence. In a deontological framework, where something like the categorical imperative is central, it is of less moral relevance (it is obviously of relevance, though, that voting has effect collectively).

${ }^{5}$ One might, for instance, argue that Brennan's conclusion conflicts with the basic moral ideas of democracy, for instance as formulated by Rawls: the conception of society as a fair system of cooperation between free and equal persons (Brennan could reply, however, that those basic moral ideas support his conclusions). Another strategy would be to argue that Brennan should have concluded, not with epistocracy, but a minimal state, since it may be argued that whereas epistocracy will reduce incompetent voters' authority in matters concerning both themselves and others, a minimal state will only reduce their authority over others.

"I will follow Brennan in speaking interchangeably about "qualified disagreement" (Estlund) and "reasonable disagreement" (Rawls), since they are closely related and the differences do not matter much for my argument. For the sake of argument, we will, like Brennan and Estlund, leave open for now what counts as "qualified". Brennan discusses this objection more thoroughly in "Epistocracy Within Public Reason" (2014).

${ }^{7}$ The comparison also rests on a consequentialist argument: epistocracy would lead to better consequences, better decisions, than democracy.

${ }^{8}$ Brennan would probably reply that voter exams and voting age laws are in the same moral boat in this respect. They are both attempts to "track a morally important distinction which all reasonable people could accept, but would do so imperfectly, in a way which not all reasonable people could accept" (Brennan 2011: 719). We cannot go into the issue of children's suffrage here, but suffice it to say that I am not fully convinced that competence is the sole, or even the primary, justification for denying children the vote. Moreover, there may be additional reasons for criticizing Brennan's comparisons of the relative injustice of voting age laws and voter exams. Indeed, I really wonder whether one can fruitfully make these comparisons in a single page or two. For instance, does it matter to the degree of injustice of voting exams if performance on these turned out to be largely genetic? Does it matter that historically oppressed groups may fail the exam more often than privileged groups? Or that well-off families would be able to provide for their offspring something like the Princeton Review, a company offering test preparation to help with college admission, thus assisting them to pass the voter exam? These are deep and difficult questions, but they are the types of questions that have to be answered in order to determine whether voting exam laws are more or less just than voting age laws.

${ }^{9}$ Note that Brennan does not concern himself with the limits of natural talents: those falling under the threshold should not vote, period, notwithstanding whether it is due to a lack of effort or lack of talent. My concern, though, is with the duty to 
educate oneself. If we accept that "ought" implies "can' in this area at least, we must add "within the limits of one's natural talents."

${ }^{10}$ The following discussion is indebted to Baron and Seymour Fahmy's (2009) discussion of how much latitude Kant allows for the duty of beneficence.

${ }^{11}$ I leave open whether it is a duty. Kant calls it an "indirect duty" (Kant, 1998).

\section{References}

Anderson, E. (2007). Fair Opportunity in Education: a Democratic Equality Perspective. Ethics 117(4): 595-622. https://doi.org/10.1086/518806

Baron, M., \& Fahmy, M. S. (2009). Beneficence and Other Duties of Love in The Metaphysics of Morals. In T. E. Hill (Ed.), The Blackwell Guide to Kant's Ethics (pp. 209-228). Oxford, UK: Wiley-Blackwell. https://doi.org/10.1002/ 9781444308488.

Brennan, J. (2009). Polluting the Polls: When Citizens Should Not Vote. Australasian Journal of Philosophy, 87(4): 535-549. https://doi.org/10.1080/ 00048400802587309

Brennan, J. (2011). The Right to a Competent Electorate. The Philosophical Quarterly, 61(245): 700-724. https://doi.org/10.1111/j.1467-9213.2011.699.x

Brennan, J. (2012). The Ethics of Voting. Princeton: Princeton University Press.

Brennan, J. (2014). Epistocracy Within Public Reason. In A.E. Cudd \& S.J. Scholz (eds.), Philosophical Perspectives on Democracy (pp. 191-204). Dordrecht: Springer Science \& Business Media. https://doi.org/10.1007/978-3-319-02312$0 \_14$

Caplan, B. D. (2007). The Myth of the Rational Voter: Why Democracies Choose Bad Policies. Princeton: Princeton University Press.

Estlund, D. M. (2008). Democratic Authority: A Philosophical Framework. Princeton, N.J.: Princeton University Press.

Kant, I. (1991). The Metaphysics of Morals. Cambridge, U.K.: Cambridge University Press.

Kant, I. (1998). Groundwork of the Metaphysics of Morals. Cambridge, U.K.: Cambridge University Press.

Lawson, K. (2007). Lifelong Learning: Conceptual and Ethical Issues. In D. N. Aspin (ed.), Philosophical Perspectives on Lifelong Learning (pp. 109-113). Dordrecht: Springer.

Rawls, J. (1997). The Idea of Public Reason Revisited. The University of Chicago Law Review, 64(3): 765-807. https://doi.org/10.2307/1600311

Somin, I. (2015) The Ongoing Debate Over Political Ignorance: Reply to My Critics. Critical Review, 27 (3-4): 380-414. https://dx.doi.org/10.1080/08913811. 2015.1139283

Talisse, R. B. (2006). Democracy and Ignorance: Reply to Friedman. Critical Review, 18(4): 453-466. https://doi.org/10.1080/08913810608443672

Wain, K. (1991). Lifelong Education: a Duty to Oneself? Journal of Philosophy of Education, 25(2): 273-278. https://doi.org/10.1111/j.1467-9752.1991.tb00647.x

Wood, A. (2009). Duties to Oneself, Duties of Respect to Others. In T. E. Hill (ed.), The Blackwell Guide to Kant's Ethics (pp. 209-228). Oxford, UK: WileyBlackwell. https://doi.org/10.1002/9781444308488 